\title{
Pulmonary alveolar microlithiasis: a rare cause of right heart failure
}

\author{
Gopal Chandra Ghosh, Bhimaray Kategeri, Krishnarpan Chatterjee, Brijesh Sharma
}

Department of Internal Medicine, PGIMER \& Dr RML Hospital, New Delhi, India

\section{Correspondence to} Dr Gopal Chandra Ghosh, gcghosh86@gmail.com

\footnotetext{
To cite: Ghosh GC, Kategeri B, Chatterjee $\mathrm{K}$, et al. BMJ Case Rep Published online: [please include Day Month Year] doi:10.1136/bcr-2013010218
}

\section{DESCRIPTION}

A 19-year-old boy presented to us with progressive shortness of breath for 5 years and bilateral swelling of feet for 1 month. His elder brother had similar problems and died of some undiagnosed respiratory condition at the age of 23 . On examination the patient was tachypnoeic (respiratory rate of $32 / \mathrm{min}$ ), with presence of bilateral pitting pedal oedema, tender hepatomegaly of $15 \mathrm{~cm}$ and raised right jugular venous pulsation. Auscultation revealed inspiratory crackles throughout the lung field, more in bilateral basal region with loud $\mathrm{p}_{2}$ component of second heart sound. Features of type 1 respiratory failure were seen in arterial blood gas analysis. Chest radiography (figure 1 ) showed bilateral diffuse sandstorm-like micronodules which were more in the lower lung fields. The cardiac silhouette and diaphragmatic surfaces could not be delineated properly. High resolution CT (HRCT) scan of chest (figure 2) revealed diffuse ground glass opacities with thickening and calcification of interlobar and interlobular septae. A restrictive pattern of lung disease was present in the pulmonary function test and two-dimensional echocardiography revealed pulmonary arterial hypertension (pulmonary artery systolic pressure of $66 \mathrm{~mm} \mathrm{Hg}$ ) with dilated right ventricle. Transbronchial lung biopsy showed presence of multiple small round calcific nodules over the alveolar wall. A final diagnosis of pulmonary alveolar microlithiasis (PAM) with cor pulmonale was established.

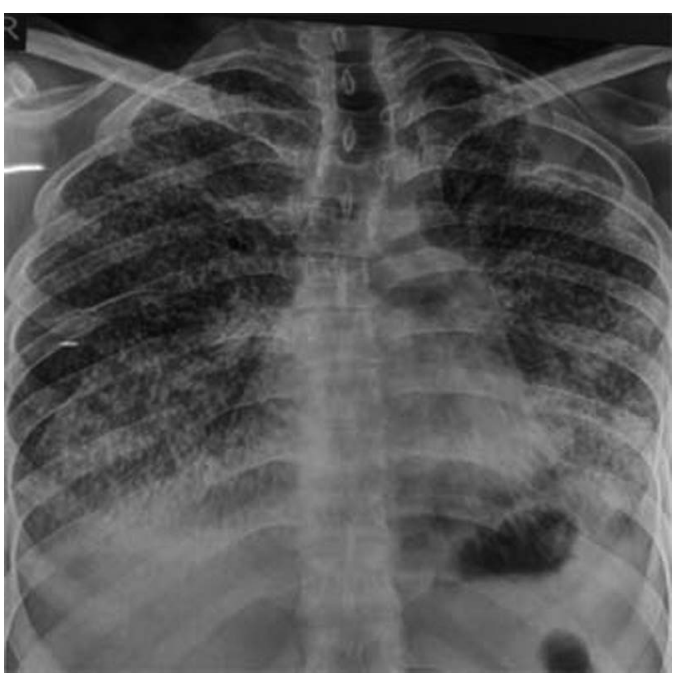

Figure 1 X-ray chest posteroanterior view showing diffuse, bilateral sandstorm-like micronodules, more in the lower lung fields. Cardiac silhouette and diaphragmatic borders are obscured.

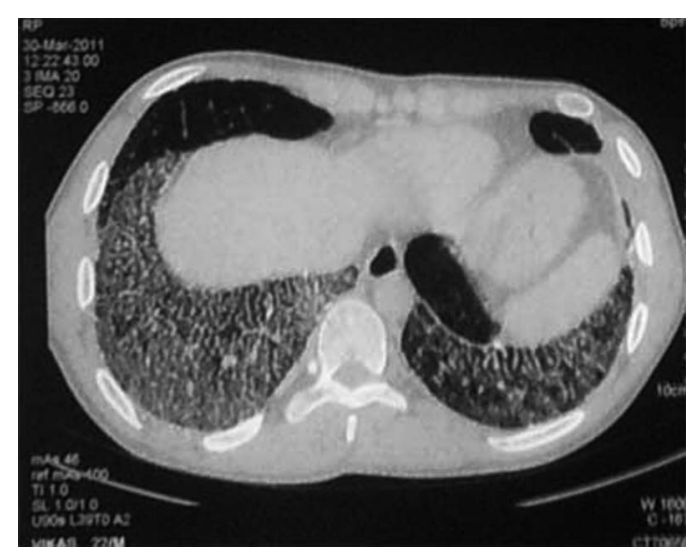

Figure 2 High-resolution CT scan of chest showing diffuse ground glass opacities with thickening and calcification of interlobar and interlobular septae.

The patient was managed with high flow oxygen and diuretics and then referred for lung transplantation. Counselling of the family members was conducted regarding the problem and they were advised screening.

PAM is an uncommon idiopathic disease characterised by microliths in the alveoli and was first described by Friedrich in 1856 and then by Harbitz in 1918. In 1957, Sosman emphasised that $50 \%$ of the cases were familial. It is regarded as an autosomal recessive lung disease and mostly reported from Asia and Europe. ${ }^{1}$ Inactivating mutations in the SCL 34A2 gene have been reported in familial cases of PAM. This gene encodes a type IIb sodiumphosphate cotransporter that is expressed in type II alveolar cells. ${ }^{2}$ A specific therapy for PAM is not yet available. $^{2}$ Lung transplantation remains the only possible treatment for end-stage disease. ${ }^{3}$

\section{Learning points}

- Pulmonary alveolar microlithiasis is a rare familial lung disorder which can rarely present with pulmonary hypertension and right heart failure.

- In a tuberculosis endemic country like India, it mimics military tuberculosis.

- No definite medical treatment is still available, although lung transplantation may be an option in patients with end-stage lung disease.

Contributors All the authors have contributed in preparing the manuscript, writing the case report, taking decision regarding publication.

Competing interests None. 
Patient consent Obtained.

Provenance and peer review Not commissioned; externally peer reviewed.

\section{REFERENCES}

1 Gayathri Devi HJ, Mohan Rao KN, Prathima KM, et al. Pulmonary alveolar microlithiasis. Lung India 2011;28:139-41.
2 Yin J, Shen K. Pulmonary alveolar microlithiasis in a child. N Engl J Med 2011; 364:e49.

3 Raffa H, El-Dakhaknny M, Al-Ibrahim K, et al. Single lung transplantation for alveolar micro-lithiasis: the first clinical report. Saudi J Kidney Dis Transp/ 1996;7:189-93.

Copyright 2013 BMJ Publishing Group. All rights reserved. For permission to reuse any of this content visit http://group.bmj.com/group/rights-licensing/permissions.

BMJ Case Report Fellows may re-use this article for personal use and teaching without any further permission.

Become a Fellow of BMJ Case Reports today and you can:

- Submit as many cases as you like

- Enjoy fast sympathetic peer review and rapid publication of accepted articles

- Access all the published articles

- Re-use any of the published material for personal use and teaching without further permission

For information on Institutional Fellowships contact consortiasales@bmjgroup.com

Visit casereports.bmj.com for more articles like this and to become a Fellow 